\title{
Strategies to support foreign language learning in large classes: a systematic literature review
}

\author{
Ulil Amri Nasiruddin - Sahril M.Hum
}

DOI: 10.18355/XL.2018.11.01.01

\begin{abstract}
The type of this research is called systematic literature review which is a qualitative approach to literatures from several publishers. The study focuses on solutions in teaching foreign language in large classes in terms the number of students in the single classroom for a single teacher needs to deal with as their daily responsibility as a foreign language teacher in aligning with determining what kind of strategies foreign language teachers could use as general strategies for large sized classes. First, I identified the database. Second, I selected relevant publications available based on the keywords of this topic. In the third phase, I picked some proper articles by reading the titles and abstracts. Fourth, I read each article to appraise and determine the focus of the study. In the final stage, I analyzed and combined the data based on the relevancy. The following databases used after consulting with librarians and topic professors: ERIC ProQuest, Proquest, Scopus, and Taylor and Francis Publishers. Nowadays, there is technology ready to deploy to help the teacher in their classrooms. Voice and audio players, internet, mobile devices, downloadable and customizable programs can be used to ease the teachers' burden and also to assess students' performance at the same time. This program and gadget can also help the student get more engagement with the learning materials and their foreign language teachers. However, foreign language teachers need to have skills to arouse students' awareness to learn the foreign language. However, without students' willingness to cooperate, there will be no classroom to conduct. Classroom democracy always works; where the students decide their goals and check their progress.
\end{abstract}

Key words: large classes, foreign language, systematic literature review

\section{Introduction}

English taught in Indonesian classrooms for many years. The teaching starts in secondary schools, where students are considered mature enough to learn any foreign language, which is around 13 years old. Classroom dynamics always changes from time to time; no class is precisely the same each year. Therefore, skillful teachers are needed to tackle constant changes ever. Students, on the other hand, will always display challenging behavior for creating a positive classroom environment. However, small amount research conducted in teaching a foreign language in big classes. No researcher plainly shows that small classes are better than large classes or the other way around. About that, in some countries, large classes are inevitable. In some cases, small classes are also unavoidable.

Foreign language (FL) learning in large classes has been around for more than three decades. The earliest study found in this area written in 1982 by Nerenz. It was a self-reflective report on how the writer managed a big number of students in one class as an FL teacher by having a positive perception towards the class and the students. Nowadays in most cases, FL teachers do not have enough pedagogical knowledge of how to manage large classes, let alone to introduce and make their students sufficient towards the targeted language.

Within the Indonesian context, in most cases, Indonesian classrooms face a vast number of students with not very experienced teachers. The number of students,

XLinguae, Volume 11 Issue 1, January 2018, ISSN 1337-8384, eISSN 2453-711X 
compared to the teachers, in most cases, is overwhelming. The ratio of 40 students and one teacher was typical in most of the secondary schools in Indonesia. The Ministry of Education and Culture (2003) as a part of the Indonesian Ministry of Education published regulation. Stating that the ratio of teachers and students for year 7 through 9 secondary students should not more than one teacher and 32 students, and for year 10 to 13, it should not be more than one teacher and 34 students. However, in most cases, one English Foreign Language (FL) teacher does not handle just one classroom the FL teacher is expected to manage more than one class. So, the number can go as high as around 800 students for one English FL teacher. In some cases, based on my experience as a teacher and English teacher trainer in South Sulawesi, Indonesia, these FL teachers gave up on their classes; they just gave worksheets to students and did not engage them in such learning activities as listening and speaking. In Indonesia, English FL teachers need strategies that they can use in conditions where they face an overwhelming number of students and where long working hours demanded to them. The strategies should be able to lessen their burden and expectations and help them achieve goals set by the government.

Listening and speaking as the focus of approaches that applicable in classrooms, are the oldest form of communication and probably the most used language skills in the world. Most English FL teachers in Indonesia would agree if asked whether listening is crucial for language learning as the first means of encountering and being exposed to the targeted foreign language. Listening comprehension is also the foundation of language learning. However, as Vandergrift (2007) stated, not many foreign language learners and practitioners conduct research in listening comprehension. It is safe to say that not many FL teachers want to focus their teaching on this skill, particularly when big classes are concerned. On the other hand, if we concentrate on other skills, such as speaking, many FL teachers regard speaking fluency as a yardstick to measure a student's language competence. These teachers define fluency as the ability to converse with others, much more than to read, write, or comprehend oral language. They regard speaking as the most important skill to acquire; further, they assess students' progress regarding their accomplishments in oral or spoken communication. Nunan (1991) stated that success in language learning is measured regarding the ability to carry out a conversation in the target language. However, speaking skill is rarely practiced in classrooms. Hardjanti (2011) reported that the Indonesian curriculum considered as making students do too much memorize. As a result, Indonesian students do not have sufficient ability to think critically and analytically. We could also say that the Indonesian English as a foreign language curriculum focuses on grammatical and translation methods. In many cases, Indonesian English FL teachers push their students extensively to memorize and translate word-by-word. It is perhaps acceptable if the students have good English dictionaries, such as Cambridge and Oxford learners' dictionary; however, most schools do not have them. Teachers can still change their way of teaching, from memorizing vocabularies to understanding the language through its context which can affect students' long-term memory on English vocabularies as Gendreau (2003) Language context is the very foundation of vocabulary acquisition.

Therefore, the needs of understanding and being self-aware of useful strategies in learning English as a foreign language in large classes are paramount for the teachers; to understand and implement the knowledge of classroom management is crucial in the field. Effective teacher mostly means successful students.

In Indonesia, English is still a foreign language. However, the Association of Southeast Asian Nation free trade area (AFTA) has already implemented. In another word, big economic players like Singapore and Malaysia, where English is a second language, will be able to enter Indonesian work and trade market without any limitation. Furthermore, the Indonesian Directorate of Higher Education (2015) stated that all Indonesian state university lecturers should pass at least 510 TOEFL score to 
get new state acceptance, which is updated every five years. It means that better English qualification is needed for future generation for them to compete

\section{Method}

A systematic review of the literature was undertaken to collect and synthesize studies of teaching foreign languages. First, I identified the database. Second, I selected relevant publications available based on the keywords of this topic. In the third phase, I picked some proper articles by reading the titles and abstracts. Fourth, I read each article to appraise and determine the focus of the study. In the final stage, I analyzed and combined the data based on the relevancy. The systematic literature review posed the following research questions. What are the strategies for creating positive classroom environments of large foreign language classes?

\section{Study Selection Process}

Systematic literature reviews conducted by focusing on the following search terms: First; (teacher strategies), (foreign language learning) and (large size classes). Second; (strategies), (foreign language), and (large classroom sizes). Third; (teacher strategies), (foreign language teaching), and (large classes). The three combinations of keywords were used to get the best and more accurate findings in the database. The data collected from the databases taken from reports and scholarly journals. The published research addressed was beginning as old as 1982 to the most recent 2015. The following databases used after consulting with librarians and topic professors: ERIC ProQuest, Proquest, Scopus, and Taylor and Francis Publishers.

Most of the articles excluded because they do not have correct focuses for the titles and theses generated in this systematic literature review. That decided after reading the whole abstracts and methods in each article. Some items found to be having correct focuses based on the titles, but later on, I found out it was not about foreign language teaching. It talks about large classes, but regarding teaching technical computer engineering. A total of 31 articles used in this systematic literature review.

A total of ten published articles discussed the issue of large classes in foreign language teaching. The oldest report created in 1982 and the newest is a journal article in 2015. Fourteen articles discuss classroom management in foreign language teaching in large classes. Two articles talked about teaching listening skills by using the intended keywords. One article about speaking and the article is research conducted in 2010 by a survey. Two articles reported teaching reading; they published in 2013 and 2014. One article about writing and was published in 2015; it was a literature review. Lastly, four articles are dealing with teaching vocabulary; all of them published in 2015. Most vocabulary research obtained their data by conducting pre and post-tests. 


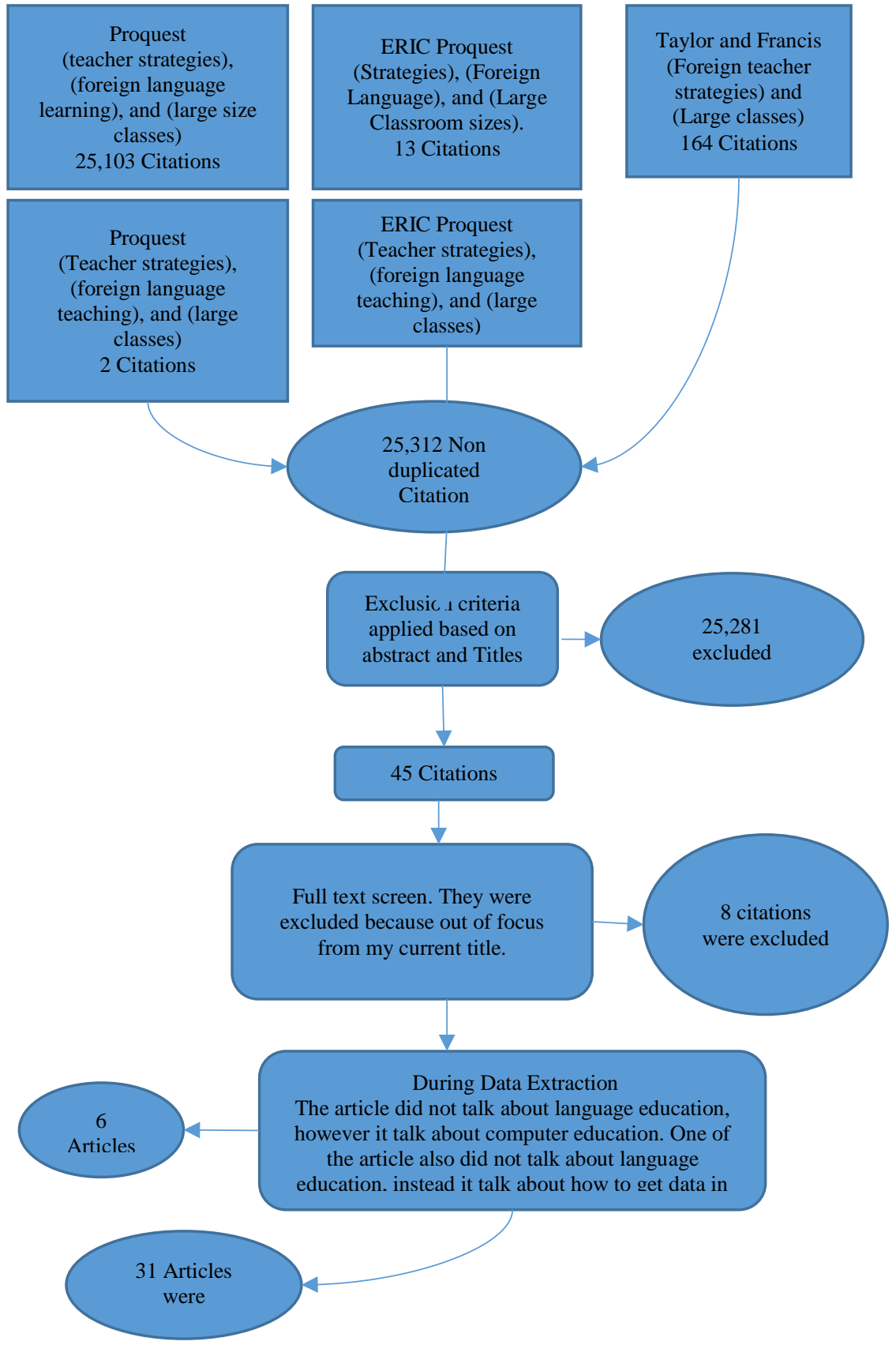

Figure 1: Study Selection Process 


\section{Class and students management}

Dealing with large classes, as mentioned before, needs a more bold strategy for delivering learning materials. Nolasco and Arthur (1986) tried to introduce the pair and group work to a native EFL teacher from England that was assigned in Morocco to teach English. Most of the native EFL teachers were used to teach English in small classes where English is a first language, not a foreign one. Most of the teachers had difficulties in dealing with a large number of students. Therefore, Nolasco and Arthur (1986) introduce the class students' management in classrooms by using pair and group works in teaching EFL to Moroccans. As we understand that pair works, where students work in two with their classmates and they can act as their peer support and competitors at the same time, depend on how the teachers build the environment. Baleghizadeh (2010) mentioned that besides pedagogical advantages, pair works could also give students reasons to create shared goals in which they work together as a small tag team to achieve these aims. Group works, on the other hand, allow students to work on a larger scale where more opinions will matter, and also students will learn to build their social interactions within the group.

However, it is not the responsibility of teachers alone for improving students' performance. Rather, it involves the collaborative work of every stakeholder around the students. Snowball and Boughey (2012) mentioned that in large classes, some students need extra hours outside the school hours. Private courses or individual awareness could be the way to have the extra hours of learning outside the schools hours. For those who cannot afford for the additional private courses, can form a group study out of the school hours where they can peer study and practice more again this needs the student's awareness and willingness in learning the FL. In some cases, students need to be aware that they need the lesson to gain knowledge in classrooms. Thus, a positive relationship between teachers and students needs to be well established. Giaque (1984) stated that teachers need to believe that it is possible to accomplish great things, even teaching in large classes. Teachers need to have a positive attitude that will be passed to the students in the classrooms later on.

Classroom democracy is one of the ways to face large classes. Sakai and Chu's (2010) students felt like they needed to be involved in classroom decisionmaking, even in deciding what kind of subjects that they wanted to learn at the moment. Therefore, Sakai and Chu (2010) suggest that some types of activities in the classes need implementation regarding deciding on their goals, reflecting on what they have achieved or, in other words, learner autonomy. Such examples provided by using personal classroom diaries where a student can plan and monitor their progress in the class. This technique also works for non-native teachers where they can decide to use their local language in collaboration with the target language for delivering an effective teaching pedagogy. Rui and Chew (2013) stated some native speakers as EFL teachers in Chinese schools experience more difficulties in teaching Chinese students, compared to their local non-native speakers where they can utilize their mother tongue as a medium in learning a foreign language.

Technology can also be used to help in the classroom process. The lender (2015) stated that one of the methods that can be employed in the classroom to help EFL learning is by using blended learning, where face to face combined with computer-assisted learning. This technique is very helpful for giving the students further engagement where personal involvement was one of the difficulties in large classes. The lender (2015) proposes that if this method implemented, it will help students outside the classroom engage with their lessons. This idea is in aligning with Boughey (2012) who stated that in large classes, students need extra time outside the school hours.

XLinguae, Volume 11 Issue 1, January 2018, ISSN 1337-8384, eISSN 2453-711X 
There is also another way of using the internet as a helping tool. Dehghanpour and Hashemian (2015) mentioned that by using a web-based approach to teaching reading, obtaining a positive attitude and outcome is possible. This technique is possible because web-based instructions arouse students' curiosity as they are new to the educational world. The downside of this method is that it needs an internet connection; so, it might be not appropriate the techniques used in countries where internet connection is not widely available or even expensive for students. Still, on helping students to get better in their FL learning in large classes, Levy and Steel (2015) stated that using an electronic dictionary where it is available almost everywhere these days by using mobile devices that almost everyone has, will help the students to gain understandings and comprehensibility much faster and easier. Milutinovic (2013) has developed a portable language learning system that can be downloaded and accessed through the internet and mobile devices. Thus, it will help the students access their learning materials outside the classroom. Furthermore, on using mobile devices for helping students learn a Foreign Language, Stockwell and Liu (2015) stated that there are portability benefits from using mobile devices; however, the use of mobile devices entirely depends on the students' awareness and availability to use the mobile devices to help them learn the FL.

Muhammad (2015) implemented Communicative Language Teaching or CLT in teaching a foreign language. In Saudi, he applied Communicative language teaching to boost students' ability in using English for communication, where they believed that CLT could also open the window to the grammatical understanding of English language. CLT provides contextual meaningful language learning that everyday communication becomes the primary tool for learning. Almost the same with Muhammad (2015), Heras (2015) used Content and Language Integrated Learning or CLIL. CLIL is believed to help students grasp more meanings; it allows full learning and less stressful because it uses contexts in generating ideas in Learning a Foreign Language.

From the elaboration above, it is arguable that classroom knowledge, pedagogical knowledge, and skills in understanding students or commonly known as teacher intuition, are vital for foreign language teachers in large classes. Therefore, we have arrived in our next part of the discussion.

\section{Foreign Language Learning in Large Classes}

There has been a long time since the dispute that class size might have an effect on foreign language learning (FL). There are not many studies conducted to investigate the effects of class sizes and the outcome of foreign language learning. Based on what I found, the earliest record dealing with class size and foreign language learning was in 1982. Nerenz (1982) conducted a study on the effects of class size on students' opportunity to learn a foreign language. Nerenz (1982) found out that class sizes have an effect on the students' opportunity to learn a foreign language. Furthermore, Nerenz (1982) discovered that during small group instructions, students spent up to four times higher to speak in FL than the teacher. Different matter in large groups, Nerenz (1982) found that students spent nearly as often as the teacher is speaking in an FL. Nerenz (1982) stated that students' opportunity to learn the FL indeed was not only affected by class sizes but also the teachers' instructions in contexts. Nerenz (1982) implied that students' level of activity and quality interaction with the teacher were also affecting factors.

A different approach was taken by Giague (1984). Giague (1984) stated that a high-quality instruction could be achieved even in a very large classroom of FL. Giague (1984) mentioned that even in 60 members of students in one class, a positive classroom environment could is achievable with a proper teacher role in arranging class structure and activities. Giague (1984) mentioned that teachers' attitude and 
enthusiasm were crucial parts in creating a constructive classroom in which attitude and passion that conveyed to his students. Interestingly, Giague (1984, P.2) stated that it had been a traditional assumption and belief that teaching a foreign language must be done in a small group of students or else it is going to be less efficient. From this statement, we know that it has been more than three decades this common belief being around and accepted. In contrary to Giague (1984), Haozhang (1997) stated that in large size classes, teachers would have difficulties in controlling a large group of people and also taking feedback from the group. However, he presented some solutions to tackle this problem discussed in listening and speaking parts.

$\mathrm{Su}$ (2006) stated that one of the obstacles for teachers to teach EFL effectively is the large class size and limited teaching hours that are allocated by the government. As expected in large classes, Su (2006) found that teachers experienced difficulties in managing the noise level and disciplinary attitude in the classroom. Most teachers complained, although grouping and pair work activities are the solutions, the results are always not as the teachers expected. Implementing Giague's (1984) ideas is possible, at least for the teachers not to have over expectation over their classes and should have a positive attitude before coming to classrooms.

In 2010, there was an idea that large class size will have a detrimental impact on the students' performance. Alberts (2010) mentioned that large classes would force the teacher not to be able to engage his students personally one by one; therefore, it will lead to students' behaving, wherein smaller classes, they will behave differently. Alberts (2010) also mentioned that not all cases of misbehaving students in large classes triggered by the discomfort of being in a very large number of students in one class, rather by how the teacher delivered and gained trust to the students in the first three meetings.

Teaching small classes and teaching large classes need different approaches, as talking and giving messages to one person is different from providing information to individuals. Harfitt (2012) mentioned that there are different approaches, which can be adopted by teachers when teaching in small classes and large classes. Each has its distinctive approach and pedagogical use. Harfitt (2012) found out that some teachers believe that they were using the same methods in teaching large classes and smaller classes. However, after thorough observation, Harfitt (2012) found that there are significantly different approaches used by the same teachers who are teaching in large classes and moving to teaching in smaller classes. In smaller classes, the teachers use more a direct and personal approach rather than in teaching large classes where the teachers use group discussions in the class; the teachers only act as mediators, who mediate the students to study in their respective group.

Looking from the students' perspectives, Harfitt (2012) conducted different research. The author found out that students feel more secure if they study in smaller classes rather than large classes, the feeling of security from their peer's negative evaluation. In this case, it is a matter of culture; this kind of problem also happens in Indonesian classrooms. Students' peers often laugh at their friends, even for a small meaningless mistake. Thus, it results in less confident and less expressive students because they are afraid of others' negative evaluation, i.e., laughing matter in the classroom.

Some research findings show that there are no significant relations between the class size and the students' performance. Tom and Alonso (2015) propose that class size does not have a considerable impact on students' outcome; if they do, it will be in neglectable numbers. However, they also found that there are significant correlations between the number of students at schools and the number of teachers at schools. The higher the number of students per teacher, the higher the students' participation rates in the classrooms. Although this research based on secondary data,

XLinguae, Volume 11 Issue 1, January 2018, ISSN 1337-8384, eISSN 2453-711X 
at least it showed roughly that a large number of students in the classrooms is not the main affecting factor of students' performance; rather, the teacher's performance in the class is accountable.

In contrary to Tom and Alonso (2015), Bahanshal (2013) found that larger class size is more demanding for the teacher and requires the teacher to be more proactive and more energy draining compared to the FL teacher who teaches in smaller classes. Teachers in larger classes are demanded to have more adventurous in developing their teaching pedagogy; therefore, it needs more skills and energy for teaching in large classes than the smaller ones. However, with this idea, it elevates even more that it is not the number of students that matters; it is the teachers' skills and performance in the class that matter.

Butler (2015) mentioned that one of the major constraints of implementing Communicative Language Teaching in Southeast Asia is a large class. A Large number of students also become the reason why non-native speaker teachers do not try a new approach to their classroom pedagogy. They tend to use the same instruction over and over again. If it worked in one class, it should work in other classes. By looking at the findings, it is evident that we need to find a particular pattern that the large foreign language classroom teachers can understand and able to use and adapt in their classrooms; thus, this is the aim of this systematic literature review.

\section{Basic Language Skills}

\subsection{Listening}

Haozhang (1997) states that using tape recorders and implementing turn taking and role play for listening practice in large FL classes will help in managing the class. Teachers can lead the listening of audios and students can simultaneously record their answers in their tape recorders.

Chou (2015) used specific purposes in topics, such as English for Academic Purposes; the listening materials then will be focusing on that issue. Students able to more focused on successful listening and word index will be more accurate; thus, the ability to decipher the sound would be much easier. In other words, it lessens the cognitive load, because the materials based on certain contexts and the background knowledge of the listeners will be more supportive in helping students comprehend the language. Wang (2015) also agreed in that matter, stating that vocabulary knowledge will boost students' EFL comprehension. Vocabulary knowledge is also part of background knowledge that students already know before listening to the sentences.

\subsection{Speaking}

Chen and Goh (2010) conducted research on the importance of teachers' role in teaching speaking in EFL classrooms. However, it negates the effect of external constraints such as the large class sizes. Chen and Goh (2010) concluded that the biggest limitation in teaching speaking is not the large class size, instead of the poor state of the EFL teachers themselves, such as the low self-efficacy and pedagogical knowledge. This issue can be solved by giving the teachers proper training on classroom pedagogy and giving them enough materials that they can use in the classrooms. Haozhang (1997) also has the solution; however, it utilizes voice recorders and players to help students. This technique is very useful because it does not need non-native teachers to pronounce the words; instead, it uses the audio player to produce native voices from the original resources. The students can then record their voices through the voice recorder, and teacher can help to assess the students' performance in speaking later by playing back the recording. 


\subsection{Reading}

Huang and Hsin (2013) conducted a study on using online reading tools to perform reading in EFL exercises and assessment. The web-based program provided the students with reading materials and the students needed to guess the meanings based on the context; the web also provided help by using a dictionary. This technique will help the students track back their background knowledge by guessing the answer from the context. Wang (2014) stated that the use of sentence visualizations such as mental imaginary would help students comprehend the reading materials even more. However, this kind of method will need time for students to train them and get used to using it; also, the results showed that female students are better at using mental imaginaries than male students.

\subsection{Writing}

Alharabi (2015) stated that writing skill is one of the most valuable skills that mastering if a person wants to go to college. Doing writing will help students comprehend even more about the reading materials that they have read. EFL writing varies between students' ability to comprehend the reading materials. EFL students grasp the word form by reading other writing materials. There, the students will learn how to create correct sentences. Therefore, it is important to let the student write whatever that they have read.

\subsection{Vocabulary}

Vocabulary is the very foundation of a language. If ones do not have sufficient vocabulary, they will not be able to create meaningful sentences in the target language. Baharuddin and Ismail (2015) stated that there are many ways of learning vocabulary; one of them is the determination strategy, where learners learn the vocabulary based on the sentence used in the conversation, where background contexts influence the meanings. This method indeed is very useful to help the student comprehend the language based on the context, where it is used, not by translating the meaning word per word, wherein the end the whole meaning will be different. Hung (2015) uses digital flash cards to arouse students' memory or retrieving ability. It stimulates the students to track their background knowledge of the pictures that they saw. Nowadays digital flashcards can be used in almost every mobile device if most students have or provided by the school. The teacher only needs to begin pair or group study and supervise the class during this process.

Naemi and Foo (2015) suggested that direct and indirect strategies in learning vocabularies, which involve the students' self-awareness to learn new vocabulary. Both methods require the students' willingness to learn the vocabulary consciously. Direct strategies, more structured approaches, and indirect strategies, more like the natural approach that involves feelings and writing down any necessary feeling that they felt at the moment. Hunag and Huang (2015) proposed the use of handheld games for improving students' motivation to learn vocabulary. The game itself based on scaffolding strategies, getting more complicated along the way. This method is very useful for individual learning approach in big class sizes where students need to spend more time learning the materials after school hours. This method can also be useful in classroom study where students can use their handheld mobile device in the class and perform the activity in pairs. 


\section{Conclusion}

Large classes in FL learning are inevitable; there have been views that smaller classes are better. However, that is not always an option. Therefore, there has to be a particular strategy that teachers can implement to achieve better students' outcomes and user-friendly both for the teachers and FL students. As previously discussed, large classes will always be there; making it smaller is not an option. Foreign language teachers need to be able to accept the situation, believe in themselves, and have a positive attitude to the large FL class. Giague (1984) mentioned that it is not about the class; instead, it is about the teachers' performance in front of the class. There is technology ready to deploy to help the teacher in their classrooms. Voice and audio players, the internet, mobile devices, downloadable and customizable programs can be used to ease the teachers' burden and also to assess students' performance. This program and gadget can also help the student get more engagement with the learning materials and their FL teachers. However, FL teachers need to be able to arouse students' awareness to learn the FL. Without students' willingness to cooperate, there will be no classroom to conduct. Classroom democracy always works; let the students decide their goals and check their progress.

\section{Limitation}

There are some constraints in this systematic literature review. There might be possible research that has been done but not published online. There is a lack of research conducted exclusively on foreign language teaching in large classes. Because Keywords are also the limiting factors in this systematic literature review, more studies, and strategies not included in this study; they do not come up with the research results.

\section{9. $\quad$ Future studies}

More in-depth research about the way FL teachers can set their strategies in teaching large classes for foreign language learning is needed. It is possible to create a systematic checklist as a universal standard that any FL teachers can use.

\section{Bibliographic references}

ABDULAZIZ, A. A. 2015. The effect of explicit instruction of textual discourse markers on Saudi EFL learners' reading comprehension. English Language Teaching, 8(4), pp. 57-66. Available online: http://search.proquest.com/docview/1678730064?accountid=10910

ALBERTS, H. C. - HAZEN, H. D. - THEOBALD, R. B. 2010. Classroom Incivilities: The Challenge of Interactions between College Students and Instructors in the US. Journal of Geography in Higher Education, 34(3), pp. 439-462. doi:10.1080/03098260903502679

ALHARBI, F. 2015. Writing for learning to improve students' comprehension at the college level. English Language Teaching, 8(5), pp. 222-234. Available online: http://search.proquest.com/docview/1686755722?accountid=10910

BALEGHIZADEH, S. 2010. The effect of pair work on a word-building task. ELT Journal, 64(4), 405-413.

BAHARUDIN, H. - ISMAIL, Z. 2015. Learning strategies of Arabic language vocabulary for pre-university students' in Malaysia. Asian Social Science, 11(10), pp. 32-38. Available online:

http://search.proquest.com/docview/1679874516?accountid=10910 
BAHANSHAL, D. A. 2013. The effect of large classes on English teaching and learning in Saudi secondary schools. English Language Teaching, 6(11), pp. 49-59. Available online: http://search.proquest.com/docview/1491275441?accountid=10910 BUTLER, Y. G. 2015. English language education among young learners in East Asia: A review of current research (2004-2014). Language Teaching, 48(3), pp. 303342. doi:10.1017/S0261444815000105

CHEN, Z. - GOH, C. 2010. Teaching oral English in higher education: challenges to EFL teachers. Teaching in Higher Education, 16(3), pp. 333-345. doi:10.1080/13562517.2010.546527

CHOU, M.-H. 2015. The Influence of Topics on Listening Strategy Use for English for Academic Purposes. English Language Teaching, 8(2).

DEHGHANPOUR, E. - HASHEMIAN, M. 2015. Efficiency of using a web-based approach to teach reading strategies to Iranian EFL learners. English Language Teaching, 8(10), 30-41. Available online: http://search.proquest.com/docview/1719434075?accountid=10910

EDUCATION, I. D. G. O. H. 2015. Persyaratan Usulan Data Dosen. Indonesia: Indonesian Directorate General of Higher Education Available online: http://forlap.dikti.go.id/welcome/newsdetail/13/1.

FAROOQ, M. U. 2015. Creating a communicative language teaching environment for improving students' communicative competence at EFL/EAP university level. International Education Studies, 8(4), pp. 179-191. Available online: http://search.proquest.com/docview/1679170441?accountid=10910

GENDREAU, S. 2013. How to Remember Words When Learning a Language. Available online: http://www.lingholic.com/how-to-remember-words-when-learninga-language/

GIAQUE, S.G. 1984. Teaching Extra Large Foreign Language Classes. Available online: the United States of America:

HAOZHANG, X. 1997. Tape Recorders, Role-Plays, and Turn-Taking in Large EFL Listening and Speaking Classes. Forum, 35(3), p. 33.

HARFITT, G. J. 2012. An examination of teachers' perceptions and practice when teaching large and reduced-size classes: Do teachers really teach them in the same way? Teaching and Teacher Education, 28, pp. 132-140.

HARFITT, G. J. 2012. Class size and language learning in Hong Kong: the students' perspective. Educational Research, 54(3), pp. 331-342. doi:10.1080/00131881.2012.710091

HERAS, A. - LASAGABASTER, D. 2015. The impact of CLIL on affective factors and vocabulary learning. Language Teaching Research, 19(1), pp. 70-88. doi:http://dx.doi.org/10.1177/1362168814541736

HSIU-TING HUNG. 2015. Intentional vocabulary learning using digital flashcards. English Language Teaching, 8(10), pp. 107-112. Available online: http://search.proquest.com/docview/1719434063?accountid=10910

HUANG - HSIN-CHOU. 2013. Online reading strategies at work: What teachers think and what students do. ReCALL : the Journal of EUROCALL, 25(3), pp. 340358.

HUANG, Y.-M. - HUANG, Y.-M. 2015. A scaffolding strategy to develop handheld sensor-based vocabulary games for improving students' learning motivation and performance. Education Tech Research Dev, 2015(63), pp. 691-708. doi:10.1007/s11423-015-9382-9

INDONESIA, K. P. D. K. 2013. Peraturan Menteri Pendidikan dan Kebudayaan Nomor 23 Tahun 2013 Tentang Perubahan Atas Peraturan Menteri Pendidikan Nasional Nomor 15 Tahun 2010 Tentang Standar Pelayanan Minimal Pendidikan Dasar di Kabupaten/Kota. Indonesia: Indonesian Ministry of Education Available online:

XLinguae, Volume 11 Issue 1, January 2018, ISSN 1337-8384, eISSN 2453-711X 
http://sdm.data.kemdikbud.go.id/SNP/dokumen/SPM/Permen\%20Nomor\%2023\%20T ahun\%202013.pdf.

LANDER, B. 2015. Lesson study at the foreign language university level in Japan. International Journal of Lesson and Learning Studies, 4(4), p. 362. Available online: http://search.proquest.com/docview/1718491124? accountid=10910

LEVY, M. - STEEL, C. 2015. Language learner perspectives on the functionality and use of electronic language dictionaries. ReCALL : The Journal of EUROCALL, 27(2), pp. 177-196. doi: http://dx.doi.org/10.1017/S095834401400038X

MU-HSUAN CHOU. 2015. The influence of topics on listening strategy use for English for academic purposes. English Language Teaching, 8(2), pp. 44-54. Available online: http://search.proquest.com/docview/1658054132?accountid=10910

MUHAMMAD, U. F. 2015. Creating a communicative language teaching environment for improving students' communicative competence at EFL/EAP university level. International Education Studies, 8(4), pp. 179-191. Available online: http://search.proquest.com/docview/1679170441?accountid=10910

MILUTINOVIC, M. - LABUS, A. - STOJILJKOVIC, V. - BOGDANOVIC, Z. MARIJANA DESPOTOVIC-ZRAKIC. 2015. Designing a mobile language learning system based on lightweight learning objects. Multimedia Tools and Applications, 74(3), pp. 903-935. doi: http://dx.doi.org/10.1007/s11042-013-1704-5

NAEIMI, M. - THOMAS CHOW, V. F. 2015. Vocabulary acquisition through direct and indirect learning strategies. English Language Teaching, 8(10), pp. 142-151. Available online: http://search.proquest.com/docview/1719434091?accountid=10910 NERENZ, A. G. - KNOP, C. K. 1982. Effect of Group Size on Students' Opportunity to Learn in Second Language Classroom. ESL and the Foreign Language Teacher, pp. 47-60.

NOLASCO, R. - ARTHUR, L. (1986). You try doing it with a class of forty! ELT Journal, 40(2), pp. 100-106. doi:10.1093/elt/40.2.100

NUNAN, D. 1991. Language teaching methodology: a textbook for teachers. United States: Prentice Hall, 1991.

RUI, T. - CHEW, P. G.-L. 2013. Pedagogical use of two languages in a Chinese elementary school. Language, Culture and Curriculum, 26(3), pp. 317-331. doi:10.1080/07908318.2013.853771

SAKAI, S. - TAKAGI, A. - CHU, M.-P. 2010. Promoting Learner Autonomy: Student Perceptions of Responsibilities in a Language Classroom in East Asia. Educational Perspectives 43(1), p. 16.

SNOWBALL, J. D. - BOUGHEY, C. 2012. Understanding student performance in a large class. Innovations in Education and Teaching International, 49(2), pp. 195-205.

STOCKWELL, G. - YI, C. L. 2015. Engaging in mobile phone-based activities for learning vocabulary: An investigation in Japan and Taiwan. CALICO Journal, 32(2), pp. 299-322. doi: http://dx.doi.org/10.1558/cj.v32i2.25000

SU, Y.-C. 2006. EFL teachers' perceptions of English language policy at the elementary level in Taiwan. Educational Studies, 32(3), pp. 265-283. doi:10.1080/03055690600631218

TOM COUPE, A. O. - ALONSO, J. D. 2015. Class size, school size and the size of the school network. Education Economics. doi:10.1080/09645292.2015.1015405

VANDERGRIFT, L. 2007. Recent Developments in Second and Foreign Language Listening Comprehension Research. Language Teaching: The International Research Resource for Language Professionals, 40(3), pp. 191-210.

WANG, S. 2015. An empirical study on the role of vocabulary knowledge in EFL listening comprehension. Theory and Practice in Language Studies, 5(5), 989-995. Available online: http://search.proquest.com/docview/1685872538? accountid=10910 WANG, L. - MICHAEL, J. L. - DAVID, D. C. 2015. The effect of image quality training on reading comprehension of EFL students using the keyword method. 
Language Teaching $\quad$ Research, 19(4), 435-454. doi: http://dx.doi.org/10.1177/1362168814541718

YONG-MING HUANG. - YUEH-MIN HUANG. 2015. A scaffolding strategy to develop handheld sensor-based vocabulary games for improving students' learning motivation and performance. Educational Technology, Research and Development, 63(5), pp. 691-708. doi: http://dx.doi.org/10.1007/s11423-015-9382-9

YUKO, G. B. 2015. English language education among young learners in East Asia: A review of current research (2004-2014). Language Teaching, 48(3), pp. 303-342. doi: http://dx.doi.org/10.1017/S0261444815000105

Words: 6235

Characters: 42097 (23,39 standard page)

Ulil Amri Nasiruddin, S.Pd., M.Ed

Dr. Sahril, M.Hum

English Department

Universitas Negeri Makassar

Address: Jalan Bonto Langkasa, Banta-Bantaeng, Rappocini, Kota Makassar,

Sulawesi Selatan 90222, Indonesia

ulil.amri@unm.ac.id 